\title{
TRÊS TIPOS DE ARGUMENTO SOFÍSTICO
}

\author{
Lucas Angioni \\ Universidade de Campinas
}

Resumo: Este artigo procura esclarecer a natureza e a importância de um terceiro tipo de argumento sofístico, nem sempre reconhecido na literatura secundária: 0 argumento que, embora seja válido e constituído de proposições verdadeiras, produz uma falsa aparência de explicação científica porque apenas parece explicar de acordo com os princípios da coisa. Procuro mostrar como esse argumento pode ser bem caracterizado pelo que Aristóteles diz em Refutações Sofísticas 11. Também procuro mostrar que a quadratura do círculo proposta por Brisão pode ser contada como um bom exemplo desse tipo de argumento.

Palavras-chave: Argumentação, dialética, essencialismo, causalidade, teoria das explicações científicas, silogística

Abstract: This paper attempts to clarify the nature and the importance of a third kind of sophistic argument that is not always found in the classification of those arguments in the secondary literature. An argument of the third kind is not only a valid one, but also constituted of true propositions. What makes it a sophistic argument is the fact that it produces a false semblance of scientific explanation: its explanation seems to be appropriate to the explanandum without being so. Evidence from this kind of argument comes from Sophistic Refutations 11, and Brison's attempt to square the circle should be counted as one of its instances.

Keywords: argument, dialectic, essentialism, causality, scientific explanation, Brison.

\section{I.}

Ao distinguir tipos de argumentos sofísticos, Aristóteles certamente leva em consideração as características dos argumentos em si mesmos, quero dizer, características que, em nosso vocabulário corrente, chamaríamos de lógicas e epistemológicas. Assim, argumentos sofísticos são classificados de 
acordo com suas propriedades lógicas (se são válidos ou não) e epistemológicas (se partem de premissas aceitáveis e/ou verdadeiras, ou não). No entanto, além de levar em consideração essas características lógicas e epistemológicas, Aristóteles considera também outro fator, que é o propósito (prohairesis) com que tais argumentos são utilizados em um dado contexto de discussão. Embora Aristóteles seja sucinto quanto a esse ponto, é bem claro que o fator preponderante para demarcar um argumento como sofístico é um propósito bem determinado1: o propósito de produzir uma falsa aparência de sabedoria. ${ }^{2}$

Aristóteles afirma em Metafísica IV:

"De fato, a sofística é uma sabedoria apenas aparente, [...] a sofística e a dialética encontram-se voltadas para o mesmo gênero que a filosofia. Mas a filosofia difere de uma pelo modo da sua capacidade, e, da outra, pelo propósito de vida" $(1004 \mathrm{~b} 18-25) .^{3}$

É claro que a filosofia difere da sofística por "propósitos de vida" distintos: enquanto a filosofia se preocupa em conhecer a verdade (cf. 1004b16-17) etc., a sofística almeja apenas a sabedoria aparente. $\mathrm{Na}$ Metafísica, Aristóteles apenas retoma sucintamente algo que foi mais bem elaborado nas Refutações Sofísticas. ${ }^{4}$ Nesta obra, lemos:

"dado que para alguns parecer ser sábio é mais propício que ser sábio sem parecer sê-lo (de fato, a sofística é uma sabedoria de aparência, que não é real, e o sofista ganha dinheiro com essa sabedoria aparente e não real), evidentemente lhes é necessário parecer desempenhar a tarefa do sábio, mais do que desempenhá-la sem parecer desempenhá-la” (165a19-24).

\footnotetext{
1 Sobre o papel preponderante do propósito ou escolha, ver REEVE, 1998, p. 229; DORION, 1995, p. 212 e FAIT, 2007, p. 104-5.

2 Em 171b25-27 ss., Aristóteles introduz uma distinção entre argumento erístico e argumento sofístico: o primeiro apenas visa à vitória na discussão a qualquer preço, certamente tendo em vista produzir uma aparência ou reputação de sabedoria; o argumento sofístico, por sua vez, é aquele que, além de almejar produzir uma aparência ou reputação de sabedoria, almeja ganhar dinheiro com essa reputação. Aristóteles, no entanto, não respeita, em seu uso dos termos, essa distinção (cf. 165b7-8) e, para os propósitos deste artigo, ela pode ser ignorada.

${ }^{3}$ Todas as traduções de Aristóteles para o português neste artigo são de minha autoria.

4 Ver também Retórica 1355b16-21: "a sofística não reside na capacidade, mas no propósito".
} 
Devemos acrescentar dois comentários ao trecho traduzido. Neste contexto, "parecer" (dokein) não é uma mera noção subjetiva, mas tem forte conexão com a noção intersubjetiva de reputação e prestígio público, a partir do qual o sofista pode esperar enriquecer. Além do mais, é claro que a noção de "sábio" neste contexto é bem flexível: não se trata da "sabedoria" com ciência das causas mais altas, que é apresentada na Metafísica (981b28, 982a2 ss, 992a24) e na Ética a Nicômaco (1141a19; 1143b19); trata-se de qualquer tipo de conhecimento pelo qual um homem pode vir a ser reconhecido e reputado como "sábio" ou "sabedor", ou "conhecedor". 5

Aristóteles prossegue:

"para dizer com acerto, a respeito de cada assunto, é tarefa daquele que conhece (i) não falar falsidades a respeito daquilo que conhece e (ii) ser capaz de denunciar quem fala falsidades" $(165 \mathrm{a} 24-26)^{6}$

A segunda tarefa, como veremos, é fundamental para compreender o tipo de argumento sofístico para o qual pleiteamos maior visibilidade. Aristóteles prossegue:

"Assim, é necessário que os que desejam ser sofistas investiguem o gênero dos argumentos mencionados, ${ }^{7}$ pois isso lhes será propício. De fato, é esse tipo de capacidade que poderá fazer alguém aparentar/parecer ser sábio - e eles têm o propósito focado nisso [sc. aparentar/parecer ser sábio]” (165a28-31).

O traço essencial e distintivo da sofística, portanto, consiste no propósito de produzir, pelo desempenho em argumentos e discussões, a reputação de ser sábio - mas uma reputação sem nenhum fundamento real,

\footnotetext{
${ }^{5}$ Embora use o termo "sophia", nas passagens assinaladas acima, para indicar a sabedoria das causas mais altas, Aristóteles também o usa em acepção bem mais comum, tanto na Metafísica (981a27: "domínio de uma arte") como na Ética a Nicômaco (1141a9-12: "sabedoria não dizer nada mais senão excelência em uma dada arte”). Aristóteles parece retomar a noção geral com que termina o Sofista de Platão: o sofista é "imitador do sábio" (268c1).

${ }^{6}$ Aristóteles retoma essa divisão em 172b10-11 ("isso [sc. mostrar/denunciar quem fala algo falso] era 0 segundo ponto do propósito sofístico"), o que demonstra que suas considerações no capítulo de abertura das Refutações Sofísticas não são meramente casuais ou desarticuladas do resto da obra.

${ }^{7}$ Isto é, os argumentos que parecem ser bons argumentos, cf. 164a23 ss.
} 
uma reputação baseada puramente na aparência de um bom desempenho na arte de argumentar ou discutir. Meu próximo ponto é mostrar que essa aparência de sabedoria sem anteparo real pode ser produzida por três tipos básicos de argumentos sofísticos: (1) o argumento que aparenta ser concludente, mas não é; (2) o argumento que, embora seja concludente do ponto de vista lógica, apenas aparenta possuir proposições respeitáveis ${ }^{8}$ ou verdadeiras; (3) o argumento que, ainda que seja concludente e composto por proposições aceitáveis ou mesmo verdadeiras, apenas aparenta explicar adequadamente por que a conclusão é o caso.

Não há nenhuma dificuldade em discernir os dois primeiros tipos de argumento sofístico. O primeiro tipo consiste em argumento que, embora seja inválido, tem a aparência de ser válido. $\mathrm{O}$ segundo tipo consiste em argumento que, embora seja válido, não possui premissas respeitáveis, aceitáveis e/ou verdadeiras, mas apenas aparenta possuir premissas dessa qualidade. As evidências textuais para esses dois tipos de argumento estão além de qualquer controvérsia sensata: Aristóteles os reconhece claramente em Tópicos 100b23-26. Há, no entanto, um terceiro tipo de argumento sofístico, cuja existência ou importância devida não é reconhecida na literatura especializada. ${ }^{9}$ Não se trata do "paralogismo nas ciências", que é explicitamente mencionado no início dos Tópicos (1015-17), visto que tal tipo de argumento não é insuflado pelo propósito de ludibriar ou produzir uma aparência de sabedoria, propósito que, como veremos é o traço essencial mais decisivo de todos os argumentos sofísticos. Trata-se de um tipo de

\footnotetext{
8 "Respeitáveis" - como sugerido por Barnes, 2011/1991, p. 166 - é uma das boas traduções para "endoxa". Outras boas opções de tradução, a depender do contexto, seriam "aceitáveis" e "aceitas como verdadeiras". Não discutirei neste artigo questões sobre a natureza dos "endoxa" e seu papel na configuração da arte dialética em Aristóteles. 0 tema esteve muito na moda recentemente e qualquer discussão exigiria ou um extenso exame do estado da questão, ou uma tentativa de recomeçar do zero pelo exame apurado dos textos, como fez Reeve, 1998, o qual sustenta que "endoxa are deeply unproblematic beliefs that seem to be true to us on the basis of our experience" (p. 242). Observo apenas dois pontos: nas discussões recentes, houve confusão grave entre (i) dizer que os "endoxa" não precisam ser opiniões verdadeiras e (ii) dizer que os "endoxa" não poderiam ser opiniões verdadeiras. Na minha opinião, (i) é correto (cf. Tópicos 162a7) e (ii) é falso (cf. BARNES, 2011/1991, p. 166; SMITH, 1997, p. 78-80; Reeve, 1998, p. 233; Pritzl, 1994, p. 42-4; MUÑOZ, 1998, p. 135). O outro ponto é que muita vez "endoxon" não se aplica a uma proposição elementar, mas a uma inferência (como ocorre em Tópicos 119b38-9 ss.).

${ }_{9}$ SCHREIBER, 2003, p. 2, reconhece tripartição semelhante à que propomos ("there are three sources of sophistical appearances in argumentation: premises that appear to be what they are not, arguments that appear to be valid when they are not, and valid arguments that appear to be relevant to the matter at hand when they are nof', grifo meu), mas, embora pareça admitir a existência do terceiro tipo de argumento sofístico, não lhe dá atenção em seu livro.
} 
argumento que é tão mais perigoso e, do ponto de vista sofístico, tão mais eficaz porque satisfaz duas características que aparentam qualificá-lo como não sofístico: trata-se de argumento válido e, além do mais, constituído por premissas verdadeiras e/ou aceitáveis. Por apresentar essas duas características, esse tipo de argumento é eficaz porque seu caráter sofístico passa despercebido e, assim, o argumento cumpre seu objetivo de produzir a aparência de sabedoria. O que faz tal tipo de argumento ser sofístico, então? E por que ele é mais perigoso? O que faz esse tipo de argumento ser sofístico consiste no fato de que ele produz uma aparência de explicação científica como diz Aristóteles em 171b29, "os sofistas almejam uma demonstração aparente"10: trata-se de um argumento válido que atinge uma conclusão verdadeira por premissas verdadeiras (e/ou aceitáveis), mas que não capta, nas premissas, a causa adequada que realmente explicaria por que o fato relatado na conclusão é o que é. Esse tipo de argumento é tão mais perigoso porque mesmo os especialistas em um dado domínio científico (oi epistemones) teriam dificuldades em detectar e desmascarar seu caráter enganador. Discernir precisamente esse tipo de argumento instaura-se, assim, como uma tarefa importantíssima para discernir casos genuínos de conhecimento científico.

Nas seções que se seguem, discutirei primeiramente os dois tipos de argumento sofístico para, então, caracterizar o terceiro.

II.

Não há muita controvérsia sobre o primeiro tipo de argumento sofístico. Trata-se de argumento falacioso no sentido estrito do termo, isto é, argumento no qual a conclusão parece ser conseqüência lógica das premissas, mas não o é. Pode-se discutir se existe em Aristóteles uma noção clara de argumento válido. Não é este o lugar adequado para discussão detalhada sobre esse problema, mas cumpre elucidar que, embora Aristóteles não tenha utilizado sistematicamente nenhum adjetivo que pudesse ser traduzido como

\footnotetext{
10 Poder-se-ia objetar, é claro, que "apodeixis" não tem o sentido estrito de demonstração científica em $171 \mathrm{~b} 29$, mas o sentido mais lato de argumento correto, como é bem comum nas obras de Aristóteles. Não obstante, as evidências para a interpretação que proponho são bem fortes e não dependem dessa ocorrência de "apodeixis". E espero que meu artigo mostre, afinal, que estamos bem autorizados a tomar essa ocorrência de "apodeixis" no sentido estrito de demonstração científica.
} 
"válido", ele reconheceu com clareza que há, basicamente, duas classes de argumentos: por um lado, os argumentos nos quais, se as premissas forem verdadeiras, a conclusão não pode ser falsa e, por outro lado, os argumentos nos quais, e as premissas forem verdadeiras, a conclusão ainda poderia ser falsa. Argumentos do primeiro tipo são válidos, ao passo que os do segundo tipo são não-válidos ou inválidos. Embora existam várias dificuldades textuais e vários problemas téoricos que poderiam ser discutidos nesse contexto, é minimamente claro que Aristóteles reconhece que, em um argumento, a conclusão se impõe necessariamente apenas quando sua falsidade é incompatível com a verdade putativa das premissas (cf. Priemiros Analíticos 53b11-16). ${ }^{11}$

O vocabulário de Aristóteles para a noção de validade não é fixo. Por vezes, Aristóteles utiliza as expressões "necessário" (anakaion) e "não necessário” (ouk anankaion, ouk ananke) ou similares para demarcar a diferença entre inferências válidas e inferências não-válidas. ${ }^{12}$ Por vezes, Aristóteles usa o adjetivo assullogistos - o qual pode ser traduzido porr "inconcludente" - para demarcar que um dado argumento não estabelece sua pretendida conclusão. ${ }^{13}$ Também o adjetivo lusimos é usado nessa mesma conexão. ${ }^{14}$ Finalmente, o termo paralogismos - cuja transliteração, "paralogismo", já está incorporada ao vocabulário português - é muita vez usado para demarcar esse tipo de argumento, ${ }^{15}$ embora se deva ter cuidado quanto a esse ponto, pois o mesmo termo paralogismos pode indicar, a depender do contexto, um argumento válido com premissas falsas. ${ }^{16}$

\footnotetext{
11 Ver STRIKER, 2009, p. 80-1. Aristóteles, no entanto, não parece ter reconhecido nada como a noção de implicação material, e sua noção de validade de um argumento parece considerar a relevância das premissas para a conclusão. Ver MORRISON, 2011, p. 178-187, para excelente discussão sobre a noção de "validade devido à forma lógica". Ver também Lear [1980], cap. 1.

12 Cf. Segundos Analiticos 47a32ss.; 47b 20-21; Barnes [1981], p. 23.

13 Ver "assylogistos" em Física 185a10; Refutações Sofísticas 167b 34, 168a 21; Retórica 1401b 9, 13; 1403a 4, 11; Segundos Analíticos 77b40 (advérbio); 91b23; cf. "asymperantos" em Física 186a25-26.

14 Ver Primeiros Analiticos 70a31, 34.

15 Também o verbo "paralogizesthai" é usado do mesmo modo. Ver Tópicos 108a27, 28, 30; 156a29; Refutações Sofísticas 164a 21, 166b 21, 28; 165a 16; 169b37; 170a10; 170b38; Física 186a10, 239b5; Retórica 1402b26; $1414 \mathrm{a} 6$.

${ }^{16}$ Este ao menos parece ser o caso dos pseudographemata, que Aristóteles chama de "paralogismos" (Tópicos 101a5-17; Ref. Sof. 171b14), mas cujo erro não parece ser de ordem formal (cf. Segundos Analíticos 77b20, 28): antes, eles assumem premissas falsas no domínio de uma ciência (cf. Tópicos 101a5-17). Se eles também cometessem erros lógicos, Aristóteles não teria por que afirmar que sua refutação só poderia ser feita pelos princípios próprios de cada ciência (Ref. Sofísticas 172a47) e não pelos princípios comuns da arte dialética.
} 
Mas é o próprio termo syllogismos quw, em Aristóteles, tem um núcleo de significado claro e invariável: um "silogismo" é um argumento válido. Esse núcleo independe do significado mais específico que o termo adquire de acordo com contexto variados. Como é bem sabido, syllogismos por vezes denota o silogismo em sentido estrito, ou seja, o tipo de argumento que Aristóteles formalizou nas "três figuras", constituído por predicações elementares com um termo mediador, etc.; mas, por vezes, syllogismos denota uma noção mais ampla de "dedução" ou de "argumento", ${ }^{17}$ como é bem comum nos Tópicos. No entanto, independentemente dessa variação no sentido preciso do termo em cada contexto, syllogismos sempre preserva, em seu núcleo duro, a noção de argumento válido. É por isso que, se um dado argumento não é válido, Aristóteles diz apenas que tal argumento "não é um silogismo"18 (ouk esti syllogismos) ou "não é concludente" ["não se conclui”] (ou sullelogisthar). ${ }^{19}$ É também por isso que estamos perfeitamente autorizados a traduzir a expressão "phainomenos syllogismos" (cuja tradução literal seria "silogismo aparente") por "argumento que aparenta ser concludente" ou "argumento que aparenta ser válido". ${ }^{20}$

Não faltam exemplos para ilustrar esse tipo de argumento. A falácia da conversão proposta por Melisso é caracterizada como um argumento inconcludente e como um "paralogismo".

Da proposição "se $x$ nasceu, $x$ tem começo", Melisso pretendia assegurar a conclusão de que "se $x$ não nasceu, $x$ não tem começo". Isso consiste em julgar que o condicional "se $x$ é $F$, então $x$ é G" pode ser convertido em "se $x$ não é $F$, então $x$ não é $G$ ", o que obviamente não é o caso. $^{21}$

O que faz um argumento ser sofístico, no entanto, não é a mera "forma lógica" do argumento, tampouco o fato de a conclusão não ser

\footnotetext{
${ }_{17}$ Compare-se o uso do termo "syllogismos" em APr. 25b34 e 40b20. Ver STRIKER, 2009, p. 78-79; SMITH, 1989, p. 110; BARNES, 1981, p. 23, vai mais longe e afirma (a meu ver, sem nenhuma razão) que "syllogismos" sempre denota a noção mais ampla de dedução correta.

18 Expressões como "ouk estai/gignetai syllogismos" são muito comum nos Primeiros Analíticos: ver 26a3-4, 31-32; 26b17-19; 27a19 etc.

${ }_{19}$ Ver Primeiros Analíticos 47a30; Refutações Sofísticas 167b31, 168a31 ("ou sullelogisthai"); Tópicos $161 \mathrm{~b} 20$ ("me symperainetai").

20 Ver FAIT, 2007, p. 150: "sillogistico, cioè logicamente valido", p. 150; Pickard-Cambridge: "deduction that appear to be genuine".

21 Ver Refutações Sofísticas 167b17-8, 168b37-8 e 181a26-30, bem como Física 186a10-13. Cf. SCHREIBER, 2003, p. 135-6; DORION, 1995, p. 242, Bostock, 2006, p. 105. Tratei desse argumento em ANGIONI, 2009, p. 195.
} 
estabelecida como necessária a partir das premissas. Pessoas comuns podem usar argumentos inconcludentes, isto é, argumentos não-válidos, assim como um pesquisador científico, se não for treinado nas ferramentas lógicas, pode vir a usar um argumento não-válido na apresentação dos dados que coletou em sua observação. Nem por isso se poderia dizer que argumentos usados nesses casos são sofísticos. O que torna um argumento sofístico é seu propósito de produzir uma aparência de sabedoria. Um dos contextos mais comuns para esse tipo de situação, na Grécia antiga, era a disputa erística na praça pública, ${ }^{22}$ como a que é retratada, por exemplo, no Eutidemo de Platão. Instituídos dois lados em uma disputa argumentativa, um dos lados tenta, a partir das premissas aceitas pelo lado adversário, estabelecer uma conclusão que ou é contrária às opiniãoes do adversário, ou é em si mesma, de comum acordo paradoxal. O adversário, por sua vez, deve tentar evitar que a conclusão seja estabelecida. Se o adversário não conseguir bloquear a conclusão, será coberto de vergonha, por ter de admitir algo contrário às suas opiniões ou algo absurdo. O objetivo do sofista é vencer essa disputa e, com a vitória, cobrir-se com a aparência de sabedoria ou destreza, e, para atingir esse objetivo, sua ferramenta capital é fazer passar despercebido a seu interlocutor o caráter não-válido do argumento.

Assim, o sofista Dionisodoro faz Ctesipo admitir uma série de premissas: "Você tem um cachorro", "esse cachorro gerou filhotes" (298d8-e1), as quais são reformuladas nas premissas "esse cachorro é teu”, "esse cachorro é pai" (298e1-4), as quais levariam a concluir que "esse cachorro é teu pai" (298a4-5), o que equivale a dizer que "você é irmão dos cachorrinhos" (298e5). É bem claro que o truque sofístico reside na composição indevida dos predicados "teu” e "pai”. Se o interlocutor, Ctesipo, não consegue mostrar que a composição é indevida, não refuta o argumento e confere ao adversário aparência de sabedoria.

22 A "disputa argumentativa" (antilogia) é mencionada em Refutações Sofísticas 171 b23 (Fait, 2007, p. 155-6, que traduz o termo por "controversia"; Dorion traduz por "échanges contradictoires"; PickardCambridge: "disputation"). 


\section{III.}

O segundo tipo de argumento sofístico é aquele que é um argumento concludente, mas que assume premissas que apenas aparentam serem aceitáveis ou aceitas como verdadeiras, sem o serem. Novamente, para alcançar seu objetivo, que consiste em produzir a aparência de sabedoria, a arte sofística deverá levar o interlocutor ou adversário a admitir uma conclusão incompatível com as opiniões que assumiu desde o início da discussão. Mas, neste contexto, a arma sofística não consiste em tentar fazer passar despercebido o passo logicamente inválido do argumento - pois usa um argumento válido -, mas sim em tentar fazer passar despercebido o caráter não-verdadeiro ou não-aceitável de ao menos uma das premissas.

Um exemplo claro consiste em fazer o adversário admitir as duas premissas seguintes: "todos os opostos têm intermediários", "os contraditórios [isto é, uma afirmação e sua negação contraditória] são opostos". Daí se conclui que "os contraditórios têm intermediários", conclusão que o adversário não estaria disposto a admitir, pois antes aceita que, entre uma afirmação e sua negação contraditória, não há intermediário.

Esse argumento é válido e poderia ser formalizado como um silogismo em Barbara. Seu caráter sofístico, pelo qual o sofista conduz à conclusão contrária à opinião do interlocutor, consiste no fato de que premissa maior, "todos os opostos têm intermediários", foi assumida como verdadeira, embora, a rigor, não seja verdadeira. O caráter falso da premissa, no entanto, pode passar despercebido ao adversário que não discerne, no início do argumento, que o termo "oposto" pode ser usado de várias maneiras, duas das quais bastam para elucidar o ponto: por um lado, o termo "oposto" é usado ordinariamente como equivalente a "contrário" 23 , mas, por outro, "oposto" é o termo mais geral que se subdivide em quatro espécies, cujas propriedades específicas estão longe de ser comuns a todas: ${ }^{24}$ os contrários, os relativos, o par posse-privação e os contraditórios. Todos contrários admitem intermediários; alguns relativos ${ }^{25}$ e alguns pares posseprivação também o admitem, mas os contraditórios não admitem

\footnotetext{
${ }^{23}$ É importante notar que o próprio Aristóteles usa "oposto" (antikeimenon) no sentido específico de "contraditório" (antiphatikon) em Primeiros Analíticos II, 11-14 (cf. 61ª31; 61b18, 32; 62¹1; 62b26).

${ }^{24}$ Cf. essa noção de "opostos" em Metafísica 1018a20-21; Categorias 11b15-19 ss.

${ }^{25}$ Cf. Categorias 6b15-19.
} 
intermediário de modo algum: ou a afirmação é verdadeira (sendo a negação falsa), ou a negação é verdadeira (sendo a afirmação falsa). O sofista indevidamente - isto é, de má fé - usa o termo geral "oposto" na premissa maior, sabendo que o interlocutor muito provavelmente admitirá a premissa como verdadeira por tomar o termo na acepção específica, em que "oposto" corresponde a "contrário". Admitidas as duas premissas, o sofista, que se valeu do termo "oposto" no sentido geral, conclui, contra a opinião do interlocutor, que todos os contraditórios também teriam intermediários. É claro que a premissa maior, "todos os opostos têm intermediários", apenas aparenta ser verdadeira (porque "opostos" pode ser usado, ordinariamente, em sentido mais estrito, equivalente a "contrários"), mas é falsa (porque "opostos”, a rigor, designa a classe geral, que inclui os contrários como uma de suas quatro espécies). ${ }^{26}$

Se o interlocutor não for capaz de denunciar esse truque sofístico, ele será incapaz de evitar a admissão da conclusão contraditória e, assim, será incapaz de bloquear a aparência e sabedoria que advém ao sofista. Este último, no entanto, utilizou neste caso um argumento formalmente válido, com uma premissa maior falsa, mas cuja falsidade passou despercebida por se aparentar à verdade. ${ }^{27}$

\footnotetext{
${ }^{26}$ Há várias descrições desse tipo de procedimento, bem como uma apresentação mais precisa de sua base conceitual em Tópicos 108a29-33.

27 Esse tipo de argumento sofístico tem similaridade com os casos que Fait, 2007, p. XXII-XXIII, reconstroi com uma "premissa falsa validante". Essa premissa falsa validante seria, neste caso, que "o termo 'opostos' tem um único significado". O argumento satisfaz a forma Barbara, mas apenas porque se assumiu tacitamente tal premissa. Uma vez percebido o truque sofístico e rejeitada a premissa validante, o oponente deve distinguir os sentidos de "opostos" e, ao aplicar a cada uma das premissas o sentido pertinente do termo, se destrói a validade do argumento, porque, havendo dois significados distintos para cada ocorrência de "opostos", não mais haveria termo mediador comum. Ao rejeitar a premissa falsa validante - ou, como prefiro, o pressuposto tácito de que "opostos" tem 0 mesmo sentido nas duas premissas -, o oponente faz esse tipo de argumento colapsar no tipo precedente: o argumento apenas parece ser concludente, mas não é (porque, a rigor, é um "silogismo" com quatro termos, sem termo mediador). Esse colapso seria a razão maior para explicar porque, em 169b20-23 e 171b18-22, Aristóteles opera com apenas dois critérios para classificar argumentos sofísticos - a concludência e a "adequação à coisa" - e não parece considerar a possibilidade de argumentos sofísticos concludentes com premissas falsas. No entanto, podemos encontrar outros exemplos que não colapsam no primeiro tipo de argumento sofístico. Considere-se: "Todas as aves voam (F)/ Todos os avestruzes são aves (V)/ Todos os avestruzes voam (F)". A premissa maior é falsa, mas não é por uma suposta homonímia que sua falsidade passa despercebida. 0 sofista pode usar suas artimanhas para fazer a falsidade da premissa passar despercebida, usando, por exemplo, uma indução com vários exemplos de aves e outros animais, sob pretexto de captar o que é próprio das aves e as distinguem de outros animais.
} 


\section{IV.}

O terceiro tipo de argumento sofístico é aquele no qual a conclusão se segue logicamente das premissas e as premissas (bem como, conseqüentemente, também a conclusão) são verdadeiras. Para se compreender o caráter sofístico desse tipo de argumento, devemos considerar que seu objetivo consiste não apenas em estabelecer uma dada conclusão como verdadeira com base em premissas verdadeiras, mas em explicar por que o fato relatado na conclusão é o que é. Novamente, o sofista almeja produzir uma aparência de sabedoria. E sua aparência de sabedoria depende de um resultado no qual o adversário aparece como derrotado. Mas, neste caso, tal aparência não é produzida por levar o adversário, literalmente, à contradição, mas por apresentar uma explicação (para o fato relatado na conclusão do argumento) quando o adversário ou não tem nenhuma explicação, ou não tem uma explicação melhor. $O$ argumento assim produzido pelo sofista é tão mais perigoso (e eficaz) porque não apenas é válido e conclui algo verdadeiro a partir de premissas verdadeiras, mas sobretudo porque fornece certa explicação para o explanandum em pauta. Seu caráter sofístico advém do fato de que o sofista promove essa certa explicação ao título de explicação última e definitiva, que captaria a causa primeira pela qual o fato a ser explicado é o que é. Não se pode dizer, desse terceiro tipo de argumento sofístico, nem que ele apenas aparenta ser válido sem ser válido, nem que ele parte de premissas que apenas aparentam ser verdadeiras (ou aceitáveis) quando, na verdade, são falsas (ou não-aceitáveis). $\mathrm{O}$ que se deve dizer desse terceiro tipo de argumento sofístico é que ele apenas aparenta explicar a coisa do modo adequado, sem fornecer aquela explicação que seria a mais adequada e, em suma, a explicação científica.

As evidências textuais para esse tipo de argumento não são fáceis de discernir, pois envolvem interpretação de passagens difíceis dos Segundos Analíticos e das Refutações Sofísticas. Meus passos serão os seguintes. Primeiramente, discutirei um dos tipos de argumento que Aristóteles menciona em Refutações Sofísticas 11, em conexão com a peirástica. Em seguida, tentarei mostrar, pelo exame de algumas passagens dos Segundos Analíticos, que se trata justamente do tipo de argumento que tenho em vista, o que mostra, também, o acordo entre as duas obras.

Esse terceito tipo de argumento sofístico ocupa um lugar central na teoria aristotélica da demonstração científica. Considere-se o seguinte 
argumento: "Todos os mamíferos são mortais"; "todos os homens são mamíferos"; "logo, todos os homens são mortais". Considere-se também outro argumento: "Todos os animais são mortais"; "todos os homens são animais"; "logo, todos os homens são mortais". E ainda: "Todos os bípedes são mortais"; "todos os homens são bípedes"; "logo, todos os homens são mortais”. Todos esses três argumentos são formalmente válidos, pois são casos de Barbara. As proposições envolvidas em todos eles são também todas verdadeiras. Meu ponto é apenas o seguinte. Os três argumentos fornecem alguma explicação para o fato que se quer explicar, o fato de que todos os seres humanos são mortais. Certas teorias da explicação poderiam ficar satisfeitas com isso e renunciar a qualquer tentativa de discernir critérios adicionais pelos quais se pudesse decidir, entre essas explicações (todas elas aceitáveis e corretas), qual é a melhor, ou qual é a mais acertada, ou qual é que mais se aproxima de uma explicação última e plenamente adequada. A teoria aristotélica da explicação, no entanto, não é desse tipo: pelo contrário, Aristóteles insiste que a explicação mais adequada, aquela que nos fornece conhecimento estritamente científico, é a que capta a causa primeira do fato que se quer explicar, ${ }^{28}$ aquela que capta a propriedade relevante que, sendo atribuída ao explanandum enquanto ele é ele mesmo, torna desnecessária e inapropriada uma nova pergunta pelo porquê. ${ }^{29}$ O terceiro tipo de argumento sofístico é aquele que, valendo-se das dificuldades em discernir a causa primeira de um dado fato a ser explicado, almeja produzir a aparência de uma explicação científica, ou seja, "almeja uma demonstração aparente" (171b29).

\section{V.}

Em Refutaçôes Sofísticas 9 e 11, Aristóteles discute a peirástica, a qual consiste no uso de argumentos para discernir falsas pretensões de conhecimento científico. A tarefa que Aristóteles parece identificar como central à peirástica consiste em discernir, a partir de princípios comuns, erros

\footnotetext{
${ }^{28}$ Cf. Segundos Analíticos I 13, cf. 78a25 e 78b3-4. Desenvolvi o ponto com detalhe em ANGIONI, 2007 e ANGIONI, 2012. Ver também Angioni, "In what sense there is no science of corruptible things: an analysis of Posterior Analytics I 8".

29 Ver Segundos Analíticos 75a28-37; 85b 27-30; Física 194b18-20.
} 
formais em argumentos que pretendem avançar conhecimento científico sobre dado assunto. ${ }^{30}$

Começo por notar que há dois tipos de argumentos que não compete à peirástica discutir: os "paralogismos nas ciências", que assumem premissas falsas e concluem algo falso no domínio apropriado de uma dada ciência, e os argumentos que falham em captar a explicação primeira, que seria "de acordo com a coisa” (kata to pragma). Como já disse, não basta, para ter conhecimento científico, estabelecer conclusões verdadeiras por argumentos corretos, pois, além disso, o fato relatado em uma conclusão científica deve ser explicado "de acordo com a coisa". Assim, não compete à peirástica discutir os "paralogismos nas ciências", pois é ao geômetra enquanto geômetra que compete discernir o que alguém conclui falsamente de acordo com o método e os princípios próprios da geometria (cf. 170a31-39, 172a56). ${ }^{31}$ Tampouco parece ser competência específica da peirástica desmascarar pretensões de conhecimento científico que, sendo constituídas por argumentos válidos e proposições verdadeiras, falham em captar a causa primeira do fato relatado

na conclusão e, assim, falham em explicar tal fato "de acordo com a coisa”. Denunciar essas falsas pretensões compete ao próprio cientista, ao qual também compete discernir os "paralogismos nas ciências", pois ambas as tarefas dependem de uma boa dose de conhecimento do assunto específico tratado em uma dada ciência.

Ora, o propósito principal almejado pelo terceiro tipo de sofista é produzir uma demonstração aparente (cf. 171b29). Mas como essa demonstração aparente parece desautorizar e desacreditar a demonstração proposta por um conhecedor do assunto, o sofista acaba por produzir o efeito colateral de parecer desempenhar a tarefa da peirástica, isto é, parecer discernir e denunciar falsas pretensões de conhecimento científico.

Ora, a sofística, como vimos, almeja produzir uma aparência de sabedoria e, por isso, almeja parecer desempenhar a tarefa do sábio. Embora

\footnotetext{
${ }^{30}$ BOLTON, 1990, propõe algo bem diferente: os "comuns" em 172a30, longe de serem princípios formais da argumentação, seria os dados da experiência comum, que todos conhecem (p. 218-9), de tal modo que a tarefa crítica da peirástica não seria detectar erros formais, mas sim o acordo de uma teoria com os explananda mais básicos que ela deveria explicar (e que todos conhecem, por serem comuns). A proposta de Bolton é bem engenhosa, mas, nos limites deste artigo, não é necessário discuti-la, pois esse problema não afetará substancialmente meu ponto principal, que é reconhecer a existência e a importância do terceiro tipo de argumento sofístico.

${ }^{31}$ Cf. Segundos Analíticos 77a40-b4; 77b16-33. Ver Física 185a14-17, e Angioni, 2009, p. 82-83, 77.
} 
não exista nenhuma tarefa específica da peirástica que procurasse discernir e denunciar explicações que falham em captar a causa primeira que está "de acordo com a coisa" a ser explicada, existem argumentos sofísticos que, (i) almejando a aparência de demonstração científica (cf. 171b29), isto é, almejando produzir a aparência de uma explicação "de acordo com a coisa", (ii) ao mesmo tempo parecem desempenhar a tarefa da peirástica, pois pretendem desautorizar (e denunciar como "ignorantes", cf. 169b17-19) os próprios cientistas incapazes de produzir outra explicação que aparecesse ser mais "de acordo com a coisa".

Vejamos isso com detalhe.

A expressão decisiva, neste contexto, é "de acordo com a coisa" (kata to pragma). Intérpretes costumam entender pragma, neste contexto, na acepção geral de "subject-matter", isto é, o assunto ou domínio a respeito do qual se constitui certa ciência. ${ }^{32}$ No entanto, "pragma" neste contexto tem outra acepção, a qual é comum no Organon como um todo: trata-se da "coisa" no sentido de fato relatado na conclusão de um argumento, e, no contexto mais estrito de argumentos com pretensão de conhecimento científico, a "coisa" no sentido de fato que se quer explicar. ${ }^{33}$

Em Refutações Sofísticas 8, lemos o seguinte:

"chamo de refutação sofística e argumento sofístico não apenas o que aparenta ser um argumento concludente (ou o que aparenta ser uma refutação), sem ser um argumento concludente, mas também o argumento que, sendo concludente, aparenta ser adequado à coisa [pragma]" (169b20-23).

Para classificar argumentos e refutações sofísticas, nesta passagem, Aristóteles não fala em verdade ou falsidade das proposições (nem em aceitabilidade), mas opera apenas com dois fatores: primeiro, a concludência

\footnotetext{
32 As traduções são em geral neutras quanto a esse ponto (Dorion: "sujet en question"; PickardCambridge: "subject- matter" ou "subject at hand"; Fait: "'oggetto"), mas a conflação entre "kata to pragma" e "kata ten technen" aparecem nos comentários de DORION, 1995, p. 287, e FAIT 2007, p. 150-1. REEVE 1998, p. 230, entende "oikeion tou pragmatos" em 169b20-23 como "proper to the subject in question".

33 Cf. Segundos Analíticos 71b11; 73b28; 74b7, 33, 36; 93a22 (para definiendum cujo definiens pode ser parcialmente demonstrado); Primeiros Analíticos 46a25. Obviamente, não quero dizer que "pragma" tem este sentido em todas suas ocorrências.
} 
lógica, segundo, a adequação à coisa. ${ }^{34}$ Nas linhas seguintes, Aristóteles prossegue:

"e esses [sc. as refutações e os argumentos sofísticos que aparentam ser adequados à coisa, mas não são] são os que, ao refutar e mostrar que os adversários são ignorantes, o fazem não de acordo com a coisa [me kata to pragma ${ }^{35}$ - o que, exatamente, pertence à peirástica” (169b23-25).

O que compete à peirástica é refutar os impostores, isto é, evidenciar suas falsas pretensões de conhecimento científico. Refutações corretas, que mostram que os pretensos conhecedores são, na verdade, ignorantes quanto ao que pretendem e propalam conhecer, seguem os princípios da arte peirástica, não "de acordo com os princípios próprios da coisa", mas de acordo com fatores "comuns" (172a32). ${ }^{36}$ Meu ponto é que há um gênero de refutações sofísticas de certo modo correlato a esse tipo de refutação peirástica, pois o sofista, em todos os casos, procura produzir a aparência de que se desempenha bem na "tarefa do sábio" (cf. 165a23-24). Como é claro que uma das "tarefas do sábio" é produzir, de acordo com a arte peirástica, refutações corretas dos que propalam indevidamente ter conhecimento de algo, se pode concluir que uma das tarefas do sofista, que busca produzir a aparência de sabedoria, é produzir uma aparência de refutação dos que

${ }^{34}$ Cf. 171b18-22. Ver nota 27. FAIT, 2007, p. 134-5, julga que Aristóteles agora introduz argumentos que se tornam válidos por uma "premissa validante" que não é apropriada ao objeto. No exemplo usado por Fait, no entanto, a premissa validante é não apenas inapropriada ao objeto, mas falsa. $\mathrm{Na}$ interpretação que propomos, o terceiro tipo de argumento sofístico opera com premissas verdadeiras, mas que apenas aparentemente são adequadas à conclusão que pretendiam explicar.

350 escopo da negação "mê" recai sobre "kata to pragma", e nenhum paradoxo resulta se os particípios "elenchontes" e "deiknuntes" são tomados como presente conativo, do modo como traduzi, e tomá-los como presente conativo é bem propício para descrever procidemento do sofista, que tenta refutar, mas não alcança o objetivo, pois produz uma refutação apenas aparente. Dorion, 1995, p. 254-5, não percebe esse ponto, embora ele tenha razão contra a revisão da tradução de Pickard-Cambridge feita por Barnes [1984] (a qual, como FAIT, 2007, toma "mê" apenas com "elenchontes" mas não com "deiknuntes"), pois o que compete à peirástica é fazer de fato exatamente as duas coisas que 0 sofista tenta fazer ou tenta parecer fazer. refutar "de acordo com a coisa" e denunciar a ignorância do oponente.

${ }^{36}$ Não faz diferença para meu ponto decidir se esses fatores "comuns" são princípios formais da argumentação (mediante os quais o dialético discerne se um argumento é concludente ou não, por exemplo) ou, conforme quer BOLTON, 1990, p. 218-9, dados ordinários da experiência comum, conhecidos por todos, ou, como propõe FAIT, 2007, p. 160, generalidades que se seguem (como conseqüências) das proposições que formam o conteúdo das ciências. 
promulgam ter conhecimento científico. A refutação sofística, no entanto, apenas aparenta produzir uma refutação dos que pretendem ter conhecimento científico, e essa aparência está ligada ao fato de que o argumento sofístico não procede "de acordo com a coisa".

No entanto, esse ponto, embora seja útil, ainda é vago. Para compreender mais determinadamente em que consistem esses argumentos sofísticos - e para compreender o significado das expressões "adequado à coisa" (169b23) e "de acordo com a coisa" (171b17, 19, 21), das quais parece depender a elucidação da natureza desses argumentos -, convém dar mais atenção ao que Aristóteles fala, em Refutações Sofísticas 11, sobre a arte peirástica:

“(i) argumentos erísticos e sofísticos, por um lado, são aqueles que aparentam ser concludentes, a respeito de coisas sobre as quais a dialética é a arte de testar [peirastike], mesmo se a conclusão for verdadeira (pois ele é enganador a respeito do porquê); (ii) por outro lado, também são argumentos erísticos e sofísticos aqueles que, não sendo paralogismos que estivessem de acordo com o método de cada assunto [kata ten hekastou methodon], parecem ser conformes à arte em pauta [kata ten technen]" (171b8-12).”

Aristóteles distingue, em (i) e (ii), dois grupos de refutações sofísticas. O que é importante para este artigo é que, no passo (ii), Aristóteles toma cuidado em distinguir entre argumentos sofísticos e os chamados "paralogismos nas artes", 37 tal como os pseudographemata. Estes últimos,

${ }^{37}$ Essa distinção pode ser muito mal compreendida se julgarmos que a negação com particípio "me ontes" está apenas com a expressão "kata ten hekastou methodon", como se Aristóteles dissesse: "tous les paralogismes qui semblent conformes à la discipline, bien qu' en réalité ils ne soient pas conformes à la méthode qui convient à chaque chose" (DORION, p. 147), ou "quei paralogismi che, pur non essendo secondo il metodo della disciplina di volta in volta in questione, sembrano essere secondo quell'arte" (FAIT, p. 35). No entanto, a negacão "me" nega toda a expressão "kata ten hekastou methodon paralogismoi" (a qual é similar a "hoi tôn peri tinas epistemas oikeiôn ginomenoi paralogismoi" em Tópicos 101a6-7). Esta última expressão remete a argumentos como os pseudographemata, os quais não apenas não têm propósito de ludibriar, mas também, embora assumindo princípios próprios de uma dada ciência, concluem algo falso por assumir uma premissa falsa. O que Aristóteles quer dizer é que a segunda classe de argumentos sofísticos é diferente dos "paralogismos que estão de acordo com o método de uma dada ciência" porque (i) nem sequer são paralogismos, porque são argumentos válidos com premissas verdadeiras, mas (ii) parecem estar de acordo com a técnica ou, mais especificamente, apenas aparentam ser adequados à coisa que concluem. Chamar esses argumentos 
que Aristóteles reconhece claramente no início dos Tópicos (101a5-17), são argumentos que procedem de acordo com os princípios próprios da geometria, aceitam como verdadeiras várias proposições da arte da geometria, mas erram ao assumir premissas falsas: por exemplo, desenham semicírculos de maneira incorreta (101a15-16). Aristóteles não é muito claro sobre a possibilidade de haver em certos pseudographemata uma combinação de premissas falsas e erro lógico. Mas esse ponto não é importante para meus propósitos. O que me importa é que, tanto nos Tópicos como nas Refutações Sofísticas, Aristóteles ressalta que tais argumentos não são erísticos nem sofísticos (101a8-11; 171b12-13, 171b38-172a1). ${ }^{38}$ Exemplos desse tipo de argumentos, em 171b15-16, são a quadratura do círculo através de lúnulas e a quadratura do círculo proposta por Hipócrates. ${ }^{39}$ Já outra proposta de quadratura do círculo, a de Brisão, é classificada, em contraste com as anteriores, como sofística, e exemplifica i tipo de argumento que aparenta ser "de acordo com a coisa": 40

sofísticos de "paralogismos" é perigoso na medida em que sugere que os mesmos não são argumentos válidos nem assumem premissas verdadeiras.

38 Não constitui objeção a isso o que Aristóteles afirma em Tópicos 157a1-3 (pace Dorion, 1995, p. 288): os pseudographemata podem ter várias premissas irrelevantes e inúteis para a conclusão almejada, e isso prolonga seu tamanho, mas por si só não os torna erísticos. 0 que os tornaria erísticos seria o propósito de prolongar 0 argumento usando premissas inúteis e irrelevantes para evitar que o oponente perceba em que passo reside a falsidade (ou de que passo do argumento depende a falsidade da conclusão). Por outro lado, FAIT, 2007, p. 152, questiona a possibilidade de haver pseudographemata com conclusões verdadeiras. Mas não preciso discutir esses pormenores para meus objetivos.

${ }^{39} \mathrm{~A}$ respeito dessas quadraturas, a informação é escassa. Não é claro nem sequer se a quadratura através de lúnulas é a mesma que se atribui a Hipócrates de Quios ou não. Ver HEATH, 1921, p. 185; 1949, p. 49; ROSS, 1936, p. 464; 1949, p. 491; MUELLER, 1982, p. 151, n 20; LLOYD, 1987, p. 120-5; DORION, 1995, p. 282-5 e FAIT, 2007, p. 151-2, o qual julga, contra a opinião da maioria, que ambas as quadraturas são a mesma. Por outro lado, basta para meus objetivos neste artigo discutir a quadratura de Brisão, sem discutir a de Antifonte, mencionada em 172a7. Aristóteles não parece considerá-la um "pseudographema" (cf. 171b34-172a7), mas um sofisma, embora não homogêneo à quadratura de Brisão. $\mathrm{O}$ argumento de Antifonte envolve uma falsidade (pois ignora a divisibilidade ao infinito das grandezas) e, por essa razão, talvez ele possa ser classificado sob o segundo tipo de argumento erístico: aquele que, para produzir a aparência de sabedoria, assume premissas que parecem respeitáveis e verdadeiras, mas não o são.

40 Para interpretação diversa desse passo das Refutações Sofísticas, ver DORION, 1995, p. 280. A meu ver Dorion perde de vista critérios mais refinados pelos quais (i) os argumentos sofísticos pudessem ser distinguidos dos "paralogismos nas ciências" e (ii) dois tipos de quadratura, a das lúnulas e a de Brisão, pudessem ser mais bem distinguidos. 
"mas, do modo como Brisão propõe a quadratura do círculo (...), porque não é de acordo com a coisa [kata to pragma], por isso é sofístico". (171b16-18)

Aristóteles não afirma, no passo (ii) de 171b8-12, que argumentos sofísticos desse tipo têm conclusões verdadeiras. Mas seu cuidado em distingui-los dos "paralogismos nas ciências" 41 tem exatamente esse efeito. $\mathrm{O}$ objetivo de Aristóteles não é apenas pôr em contraste, de um lado, argumentos sofísticos que apenas aparentam ser apropriados à coisa e à ciência em questão e, de outro, paralogismos que são apropriados à ciência em questão. Aristóteles também almeja pôr em contraste o fato de que tais paralogismos chegam a conclusões falsas (através de ao menos uma premissa falsa), ao passo que os argumentos sofísticos do terceiro tipo chegam a conclusões verdadeiras. Assim, Aristóteles prossegue:

"Por conseguinte, (a) é um argumento erístico aquele que aparenta ser um argumento concludente a respeito dessas coisas. (b) Também o argumento que aparenta ser concludente de acordo com a coisa [kata to pragma], mesmo que ele seja um argumento concludente, é erístico, porque ele aparenta ser de acordo com a coisa, de modo que é enganador e injusto" (171b18-22).

Se por 171b8-12 se estabelece que argumentos sofísticos do terceiro tipo têm conclusões verdadeiras (diferentemente dos "paralogismos nas ciências”), e por 171b8-12 e 171b18-22 se estabelece que argumentos sofísticos do terceiro tipo são concludentes, resulta que o traço distintivo que os faz ser sofísticos é o fato de aparentarem ser "de acordo com a coisa".

Em 171b18-22, como em 169b20-23, Aristóteles não fala em verdade ou falsidade (ou aceitabilidade) das proposições, mas opera apenas com dois fatores para classificar tipos deargumentos erísticos: são argumentos erísticos, por um lado, aqueles que apenas aparentam ter concludência lógica e, por outro, aqueles que, mesmo sendo concludentes do ponto de vista lógico,

\footnotetext{
${ }^{41}$ De fato, as quadraturas através de lúnulas, bem como a atribuída a Hipócrates, têm, ao menos nas versões reportadas pelos comentadores (Simplício, ad Physica 56.1-57.24), premissas falsas que são suportam a verdade da conclusão pretendida (cf. também Filopono, ad Physica 31.3-32-3). PseudoAlexandre, ad Sophisticos Elenchos 90.12-21, não tem nenhuma razão em julgar que os princípios da quadratura de Brisão são não apenas comuns, mas também falsos.
} 
apenas aparentam ser adequados à coisa. A quadratura de Brisão se conta entre os argumentos do segundo tipo: é sofístico porque pretendeu aparentar ser adequado à coisa. No entanto, é preciso examinar mais detalhadamente o que significa ser "adequado à coisa" neste contexto, pois somente assim podemos compreender de modo satisfatório por que a quadratura de Brisão é considerada como um argumento sofístico.

Sigo a interpretação de Mueller, ${ }^{42}$ de acordo com a qual a versão da quadratura de Brisão fornecida por Proclo é a que melhor capta o que Aristóteles tinha em vista. Nessa versão, a premissa decisiva da quadratura consiste no seguinte enunciado: "há algo igual àquilo do qual há algo maior e algo menor".

Não preciso discutir se Mueller tem razão em insistir que a censura de Aristóteles incide sobre o fato de que tal princípio seria aplicável a qualquer figura plana (e não apenas e especificamente a círculos), em detrimento da interpretação segundo a qual a censura de Aristóteles incidiria antes sobre o fato de que o princípio é muito geral e se aplica também a outros gêneros no domínio das matemáticas (como números, tempos, sólidos). ${ }^{43}$ Basta-me ressaltar o seguinte. $\mathrm{O}$ contraste entre, por um lado, as quadraturas através de lúnulas (e a de Hipócrates) e, de outro, a quadratura de Brisão tem por efeito ressaltar que o terceiro tipo de argumento sofístico, diferentemente dos paralogismos que usam premissas falsas e chegam a conclusões falsas, estabelecem conclusões verdadeiras por meio de premissas verdadeiras (cf. Segundos Analíticos 75b37-76a2). Interpretação apressada desse contraste poderia presumir que, sendo as primeiras "de acordo com o método da geometria" e "de acordo com a arte [geométrica]", a segunda, a de Brisão, não poderia ser descrita do mesmo modo: não seria nem "de acordo com o método da geometria", nem "de acordo com a arte [geométrica]". A partir disso, se poderia presumir que as expressões "de acordo com o método da geometria" (171b11) e "de acordo com a arte [geométrica]" (171b12) seriam

\footnotetext{
42 Cf. MUELLER, 1982, p. 161-4, bem como FAIT, 2007, p. 154. DORION, 1995, p. 287, objeta que a versão de Proclo não indica os meios de construir uma figura retilínea igual ao círculo. Não entendo como isso poderia ser uma objeção à preferência pela versão de Proclo, pois Brisão, justamente ao avançar uma dedução correta da conclusão "existe uma figura retilínea cuja área é igual a de um círculo" sem construir a figura, mas usando princípio próprio da geometria, produziria exatamente uma aparência de demonstração matemática, a qual não seria nem "kata to pragma" nem "kata ten technen".

${ }^{43}$ FAIT, 2007, p. 155 considera uma possibilidade ainda mais "comum": Brisão se teria fiado apenas na "gramática lógica" de termos como "maior" e "menor".
} 
equivalentes à expressão "de acordo com a coisa”, usada logo mais, em 171b17, 19 e 21. Se assim fosse, a quadratura de Brisão seria considerada como sofística apenas por ser um argumento que não está de acordo com a arte da geometria (ou não está de acordo com a arte da matemática em geral). ${ }^{44}$

Essa interpretação, no entanto, não se sustenta. Se Mueller está certo ao preferir a versão de Proclo, o princípio utilizado por Brisão, sendo aplicável a outras figuras planas, é um princípio verdadeiro que pertence ao domínio da geometria, e seria muito difícil dizer que tal princípio não está "de acordo com o método da geometria" nem "de acordo com a arte geométrica”. Além do mais, em Segundos Analíticos 75b37-76a2, fica claro que, para Aristóteles, a quadratura de Brisão utilizou princípios verdadeiros e mesmo imediatos. 45

Ainda que alguém quisesse insistir que o princípio utilizado por Brisão não está nem "de acordo com o método da geometria" nem "de acordo com a arte geométrica", ainda não se provaria que o significado dessas duas expressões é equivalente ao significado da expressão "de acordo com a coisa”, nem se provaria que a razão capital para Aristóteles condenar tal quadratura como sofística seria o fato de ela não estar de acordo com a arte geométrica. Se um argumento não está "de acordo com o método da geometria" nem "de acordo com a arte geométrica", se segue que tal argumento não pode estar "de acordo com a coisa", pois a coisa, neste caso, é o círculo, um objeto específico no domínio da arte geométrica. Mas a inversa não se segue: não é verdadeiro dizer que, se um argumento não está "de acordo com a coisa [o círculo]", então ele não está “de acordo com o método da geometria" nem "de acordo com a arte geométrica". De modo similar (usando um exemplo que depende da biologia de Aristóteles), se $X$ não é animal, segue-se que $X$ não é um animal com pulmão. Mas a inversa não é o

\footnotetext{
${ }_{44}$ Parece ser esta a interpretação de Reeve, 1998, p. 231, bem como a de DORION, 1995, p. 288, 290. FAIT, 2007, p. 154 ressalta que o sofisma de Brisão, embora seja válido e use premissas verdadeiras, comete erro metodológico, mas não ficaria claro qual a natureza do erro. 0 mesmo FAIT, 2007 , p. 155, chega a considerar a possibilidade de que Brisão tenha adotado um princípio totalmente acima do domínio da matemática (ver nota anterior).

45 Cf. MUELLER, 1982, p. 164: "Proclus's version of Bryson's argument makes good sense of Aristotle's prima facie puzzling view that the argument is a valid derivation from true first principles but is nevertheless inadequate". Já DORION, 1995, p. 288, julga que Aristóteles atribui a Brisão o uso de princípios comuns, em detrimento dos princípios próprios da geometria. Ver também FAIT, 2007, p. 155.
} 
caso: não se pode afirmar que, se $X$ não é um animal com pulmão, então $X$ não é animal. À pergunta "por que a parede não respira?", pode-se de certo modo responder que a parede não respira porque nem sequer é um animal, embora a resposta mais adequada fosse dizer que a parede não respira porque não é um animal com pulmões. ${ }^{46}$ Mas daí, obviamente, não se segue que "não ser animal” e "não ser um animal com pulmões" sejam expressões equivalentes. De modo similar, à pergunta "por que a quadratura de Brisão é uma argumento sofístico?”, poder-se-ia de certo modo responder que a quadratura é um argumento sofístico porque nem sequer está "de acordo com o método da geometria", mas de modo algum se poderia inferir que "de acordo com o método da geometria" equivale a "de acordo com a coisa", e tampouco se provaria que a razão primeira para caracterizá-lo como sofístico seria não estar de acordo com o método da geometria.

A intepretação de Mueller é melhor, porém, do que a que mencionamos no parágrafo anterior. De fato, é difícil admitir que um princípio como "há algo igual àquilo do qual há algo maior e algo menor" não pudesse ser usado pelo geômetra, "na exata medida em que lhe cabe" (cf. Segundos Analíticos 76a39-40, 76a41-b2; Metafísica 1005a25-27), de modo a gerar uma especificação adequada à arte da geometria, tal como: "há uma figura plana igual àquela da qual há uma maior e uma menor”. Não procede a observação de que a premissa fundamental da quadratura de Brisão seria estranha ao domínio e aos métodos da geometria. É claro que ela é comum (cf. Segundos Analíticos 75b40-42), seja proque pode ser aplicada a outras figuras além do círculo, seja porque pode ser aplicada a outros tipos de contínuo. Mas a utilização desse princípio comum, com a especificação adequada a cada aplicação, é admitida por Aristóteles como um procedimento legítimo no método da geometria.

Ainda se poderia objetar ${ }^{47}$ que a quadratura de Brisão não seria conforme ao método da geometria porque não especificaria nenhum modo de construir a figura em questão, o quadrado com área igual à do círculo. Talvez eu possa conceder esse ponto. Que seja: a ausência de instruções para construir o quadrado com área igual à do círculo tornaria a quadratura de Brisão estranha aos métodos dos geômetras de seu tempo. No entanto, a

\footnotetext{
${ }^{46}$ Esse exemplo, bem como o argumento a respeito da noção de causa primeira, encontra-se em Segundos Analíticos 78b13-28.

${ }^{47}$ Cf. DORION, 1995, p. 287.
} 
principal razão que a torna sofística ainda seria o fato de que ela parece ser adequada à coisa - pois parece explicar, pelos princípios da geometria, a possibilidade de um quadrado com área igual à de um círculo - e parece denunciar como ignorantes os geômetras de seu tempo justamente ao parecer denunciar que o método de construção, presentemente usado por tais geômetras, não seria necessário para resolver o problema da quadratura.

VI.

Devo admitir, porém, que o texto das Refutações Sofísticas não é muito claro a respeito do significado da expressão "de acordo com a coisa". No entanto, como pretendo mostrar, minha interpretação se enquadra muito bem naquilo que Aristóteles diz em Segundos Analíticos I-9, texto no qual a quadratura de Brisão é novamente mencionada.

Vejamos a passagem relevante:

\begin{abstract}
"Uma vez que, manifestamente, não é possível demonstrar cada coisa senão a partir dos princípios de cada uma (quando aquilo que se quer provar se atribui a cada coisa enquanto ela é ela mesma), não se dá o conhecê-la, quando se prova a partir de princípios verdadeiros, indemonstráveis e imediatos. Pois é possível provar do modo como Brisão prova a quadratura. Os argumentos deste tipo provam por algo comum, que pode ser atribuído também a outro item; por isso, tais argumentos se ajustam também a outros itens não homogêneos. Portanto, não se conhece $A$ enquanto é $A$, mas se conhece apenas por um atributo concomitante" (75b37-76a2).
\end{abstract}

Aristóteles enfatiza que um argumento ainda não contaria como demonstração científica, mesmo se suas premissas fossem princípios verdadeiros e imediatos. Exemplo de argumento desse tipo é, justamente, a quadratura de Brisão: ela parte de princípios verdadeiros e, presumivelmente, imediatos, como a premissa explicitada na versão de Proclo. ${ }^{48}$ Mas tal premissa propõe, como fator supostamente relevante para explicar o fato relatado na conclusão, uma causa que se aplica também a outras coisas. Por

${ }^{48}$ Cf. MUELLER, 1982, p. 162-3. 
esta última razão, um argumento desse tipo falha em captar a causa primeira do fato que se quer explicar - aquela causa que, atendo-se precisamente ao que é em si mesma a coisa a ser explicada, explica adequadamente por que aquela coisa é do modo como é. Assim, seria preciso estabelecer a quadratura do círculo por princípios pertinentes ao círculo enquanto círculo, isto é, princípios que captassem aquilo que, especificamente no círculo, o fizesse suscetível à quadratura. Ao selecionar uma premissa que se aplica também a outras coisas, Brisão propôs como causa da quadratura do círculo um atributo concomitante (um symbebekos) ${ }^{49}$ e, nessa medida, em vez de fornecer conhecimento científico no sentido estrito, fornece apenas conhecimento por um atributo concomitante (episteme kata symbebekos). ${ }^{50}$ Como Aristóteles prossegue:

"Conhecemos cada fato não por concomitância quando o conhecemos através da coisa em virtude da qual ele é o caso, a partir dos princípios dessa coisa enquanto ela é ela mesma por exemplo, o fato de possuir ângulos iguais a dois retos, conhecemo-lo a partir dos princípios daquilo a que se atribui por si mesmo o fato mencionado" (76a4-7).

Examinei em outros contextos o significado dessa passagem condensada e difícil, ${ }^{51}$ e não caberia analisá-la com detalhe nos limites deste artigo. Basta observar o seguinte: Aristóteles usa a expressão sumbebekos, em contextos como esse, para assinalar qualquer atributo que, mesmo sendo verdadeiro a respeito de um dado sujeito, mesmo sendo necessariamente verdadeiro a respeito de um dado sujeito, mesmo sendo essencial a respeito de um dado sujeito, não capta, no contexto de uma explicação científica, a causa relevante que faz o sujeito em questão ter o atributo que se quer explicar. ${ }^{52}$ Assim, uma mesma proposição pode ser conhecida de dois modos

\footnotetext{
49 Logo abaixo explicaremos a terminologia.

50 Cf. Segundos Analíticos 71b9-10; 75b25; Tópicos 110b22, 23. Logo mais explicaremos em que consiste essa noção.

51 Cf. Angioni, 2007; explorei o assunto, ainda em ANGIONI, 2009 ("In what sense there is no science of corruptible things: an analysis of Posterior Analytics I 8") e Angioni, 2012. O comentário de BARNES, 1993, p. 134-5, a essa passagem é no mínimo desapontador.

$52 \dot{E}$ um grande preconceito, totalmente infundado, julgar que "symbebekos" sempre introduz a noção de atributo acidental. Vários intérpretes são bem cuidadosos: dizem apenas que a expressão grega para a noção de atributo acidental é "symbebekos" (o que é correto), mas não sugerem nem inferem que se possa concluir que todas as ocorrências de "symbebekos"
} 
distintos - e pode figurar como conclusão em dois silogismos bem distintos. A proposição "todo triângulo tem $2 \mathrm{R}$ " pode ser conhecida de acordo com "os princípios do triângulo enquanto triângulo" (cf. 76a5-6), o que equivale a dizer "de acordo com aquela propriedade relevante do triângulo que, por si mesma, faz o triângulo ter $2 \mathrm{R}$ ”. Mas a mesma proposição pode ser conhecida "por um atributo concomitante", isto é, por um atributo que, ainda que seja necessariamente verdadeiro a respeito de todo triângulo e permita corretamente concluir que todo triângulo tem $2 \mathrm{R}$, não capta a propriedade relevante que, por si mesma, faz todo triângulo ter 2R. Exemplo de "atributo concomitante" do triângulo seria a propriedade de ter sua extensão exaurida pelas espécies isósceles, escaleno e equilátero. ${ }^{53}$ Do mesmo modo, a proposição "duas linhas perpendiculares a uma terceira não se encontram" pode ser conhecida de dois modos distintos (cf. 74a13-16): ou porque "linhas que formam ângulos retos ao interceptarem uma terceira linha não se encontram", ou porque "linhas que formam, ao interceptarem uma terceira linha, ângulos iguais, não se encontram”. A primeira explicação introduz proposições necessariamente verdadeiras a respeito das linhas em questão e permite deduzir corretamente a conclusão, mas ela falha em captar o fator relevante que, precisamente, faz as linhas em pauta não se encontrarem..$^{54} \mathrm{O}$ fator decisivo é captado, justamente, na segunda explicação: trata-se do fato de formarem (ao cortarem a terceira linha) ângulos que são iguais de qualquer modo, isto é, sejam eles ângulos retos, agudos ou obtusos. Mesmo

designam essa noção. No entanto, essa inferência ilegítima parece ter-se sedimentado na opinião pública sobre Aristóteles. Contra ela, porém, basta notar que Aristóteles, nos Tópicos, oferece duas definições para "symbebekos" - apenas uma das quais corresponde à noção de atributo acidental, sendo a outra bem mais ampla, designando qualquer atributo que não seja nem definição, nem próprio, nem gênero (um bom exemplo seria "mortal" como atributo de "homem"). E essa noção mais ampla é também largamente utilizada nos mesmos Tópicos (ver um caso claro em 115a3-4).

${ }^{53}$ Darei mais atenção a este caso na seção seguinte.

54 "Concomitante" é tradução muito melhor para "symbebekos" neste contexto. Ora, para chamar o atributo de "sumbebekos" ou não, Aristóteles não tem em foco apenas a relação diádica entre sujeito e predicado - se tivesse, seria ininteligível dizer que homem symbebeke a Sócrates (Metafísica 981a1820) ou que triângulo symbebeke ao equilátero (Tópicos 1110b24). Aristóteles tem em foco a relação triádica entre 0 atributo em questão e a relação predicativa que ele deveria explicar. Faz pleno sentido dizer que, para explicar porque as linhas em pauta são paralelas, o fato de elas formarem ângulos retos com uma terceira é apenas algo concomitante, que "vai junto" (symbebeke) com tais linhas. Mesmo quando um atributo concomitante se segue necessariamente do sujeito a que se atribui (pela relação diádica $S-P$ ), o ponto relevante é que ele não capta a causa precisa para explicar porque tal sujeito tem o predicado que se quer explicar (pela relação triádica $C-A-B$ ) - ainda que sua atribuição seja condição sine que non para a presença dessa causa. 
se essas linhas não formassem ângulos retos, elas ainda poderiam ser paralelas entre si. ${ }^{55}$

\title{
VII.
}

Mas se poderia devidamente perguntar qual é a relação entre esses argumentos que fornecem conhecimento apenas por concomitância e argumentos sofísticos? Além da menção a Brisão em Segundos Analíticos I-9, que supomos ser um sofista, há outra conexão entre argumentos por concomitância (os quais falham em captar o fator explanatório mais relevante, relacionado àquilo que a coisa a ser explicada é em si mesma) e argumentos sofísticos (os quais falham em ser "de acordo com a coisa")?

Felizmente, temos uma conexão explícita a esse respeito, em Segundos Analíticos I-5:

\begin{abstract}
"Por isso, se alguém provar a respeito de cada triângulo (ou com uma única demonstração, ou com diversas) que cada um possui dois ângulos retos - separadamente, o eqüilátero, o escaleno e o isósceles - ainda não saberá que o triângulo tem ângulos iguais a dois retos (a não ser pelo modo sofístico), nem que isso se atribui a todo triângulo, mesmo se não houver outro triângulo além destes. Pois, neste caso, ele não saberia enquanto é triângulo, nem que todo triângulo, a não ser por contagem; mas, pela forma, não saberia que todo triângulo, mesmo se não existisse nenhum que ele não conhecesse” (74a25-32).
\end{abstract}

Aristóteles parece contemplar duas situações nesse trecho. ${ }^{56} \mathrm{Uma}$ situação seria aquela na qual alguém produzisse demonstrações separadas para cada espécie de triângulo. A esse respeito, Aristóteles diz nos Tópicos.

${ }^{55}$ Cf. Segundos Analíticos 74a13-16. Tratei desse ponto em ANGIONI, 2007 e ANGIONI, 2012. Para interpretação diversa, porém comum à minha em vários pontos, ver HASPER, 2006. É difícil imaginar o motivo obscuro que levou BARNES, 1993, p. 124, a tratar "orthai" como linhas retas e não como ângulos retos.

${ }^{56}$ Cf. ANGIONI, 2007, HASPER, 2006. 
"Por exemplo: o conhecimento de por que o triângulo tem $2 \mathrm{R}$ é por si mesmo, ao passo que o conhecimento de por que o equilátero tem $2 \mathrm{R}$ é por um atributo concomitante: de fato, porque se atribui ao equilátero ser um triângulo, de acordo com isso é que conhecemos por que ele tem $2 \mathrm{R}$ ” (110b22-25).

Nota que, neste trecho, ser triângulo é descrito como algo que se atribui como concomitante (symbebeke) ao equilátero. É claro que o jargão sumbebekos e symbebeke, em contextos como esse, estão longe de designar atributos acidentais: o jargão é usado para designar atributos que, pelo aspecto que está relevantemente em foco no contexto, são de um modo ou de outro irrelevantes. Embora ser triângulo seja um atributo essencial do equilátero e, enquanto tal, necessariamente verdadeiro a respeito de todo equilátero, ele não descreve o fator explanatório mais relevante que faz todo equilátero ter 2R (ainda que esse fator dependa do ser triângulo e seja coextensivo com ser triângulo, "ser triângulo" continua sendo algo distinto desse fator). ${ }^{57}$

Assim, se a única explicação que temos para o fato de que todo equilátero tem $2 \mathrm{R}$ é que todo equilátero é triângulo e todo triângulo tem $2 \mathrm{R}$, sem nos adentrarmos na descrição exata do fator relevante que faz todo triângulo ter $2 \mathrm{R}$, nosso conhecimento será apenas “por um atributo concomitante”, que é insuficiente para a explicação que se tem em vista. Até este ponto vai o que Aristóteles diz nos Tópicos. No entanto, o texto dos Segundos Analíticos I-5 permite ir além: permite-nos dizer que, se pretendemos dar a esse explicação a aparência de explicação última, adequada, científica, etc., então nos tornamos sofistas, pois buscamos a todo preço parecer cumprir a tarefa do sábio, e produzimos uma demonstração apenas aparente.

A segunda situação contemplada em 74a25-32 é aquela à qual já aludi alguns parágrafos antes. Suponha que alguém, já tendo exaurido demonstrações separadas para cada espécie de triângulo, agora inferisse, por contagem, que "todo triângulo tem $2 \mathrm{R}$ " porque "todo triângulo é ou escaleno, ou isósceles ou equilátero", e “tudo que é ou escaleno, ou isósceles ou equilátero tem $2 \mathrm{R}$ ”. Novamente, essa suposta demonstração falharia em descrever exatamente o fator mais relevante que faz todo triângulo ter $2 \mathrm{R}$, e o

${ }^{57}$ Algo similar ocorre com "homem", "Sócrates" e "curável" em Metafísica 981a18-20. 
atributo "ser ou escaleno, ou isósceles ou equilátero" contaria apenas como um "concomitante". De modo similar, se pretendemos dar a esse explicação a aparência de explicação última, adequada, científica, etc., então nos tornamos sofistas.

Não é por acaso, portanto, que Aristóteles relaciona o "conhecimento por um atributo concomitante" e "o conhecimento pelo modo sofístico" na primeira tentativa de definição do conhecimento científico em Segundos Analíticos I-2:58

"Julgamos conhecer cientificamente uma coisa qualquer, sem mais (e não do modo sofístico, por concomitância), quando julgamos reconhecer, a respeito da causa pela qual a coisa é, que ela é causa disso, e que não é possível ser de outro modo” (71b9-12).

Em suma: o terceiro tipo de argumento sofístico que Aristóteles reconhece, e cujo exemplo pode ser discernido na quadratura do círculo formulada por Brisão (ao menos na versão de Proclo), é precisamente o argumento que, ao propor uma explicação para o fato relatado na conclusão, falha em captar o fator explanatório mais relevante, aquele que mostraria por que a coisa, em si mesma, tem a propriedade que se quer explicar. Esse tipo de argumento sofístico apresenta, como fator explanatório para o fato relatado na conclusão, um "atributo concomitante" que ou é irrelevante ou é insuficiente para a explicação que se queria dar. E é essa falha que Aristóteles descreve, nas Refutações Sofisticas, com a expressão "não de acordo com a coisa" [ou kata to pragma]. Podemos dizer que tal expressão, nesse contexto, equivale ao que Aristóteles expressa, no contexto dos Segundos Analíticos, por expressões como kath' hauto e hêi auto, "de acordo com a coisa em si mesma). ${ }^{59}$

\section{VIII.}

Finalmente, nas Refutações Sofísticas, parece haver uma demonstração aparente similar aos silogismos sugeridos em Segundos Analíticos 74a25-32. A reconstrução desse caso, no entanto, é bem controversa. A leitura

${ }^{58} \mathrm{O}$ exame dessa definição foi meu propósito central em Angioni, 2007.

${ }^{59} \mathrm{Cf}$. Segundos Analíticos 73b27-32; 75a28-37; 85b7. 
tradicional da passagem em questão (168a40-b4) consiste em discernir um silogismo inválido de terceira figura:

“Todo triângulo tem $2 \mathrm{R}$ "

"Todo triângulo é uma figura (ou algo primeiro, ou princípio)"

Logo, "toda figura (ou todo primeiro etc.) tem $2 \mathrm{R}$ ". ${ }^{60}$

Não é essa a correta interpretação do passo, no entanto. Seria difícil compreender de que modo geômetras ficariam embaraçados com tal falácia e se deixariam refutar e "desmarcarar" por ela. Um rápido treino nos Analíticos (do tipo a que se alude em Metafísica 1005b3-4) seria suficiente para torná-los capazes de discernir o caráter ilegítimo da inferência. ${ }^{61}$

Interpretação muito melhor se obtém se o silogismo em questão for visto como uma "demonstração aparente" em Barbara e, para tanto, basta notar dois pontos: (i) hoti, ${ }^{62}$ em 168b2, tem o sentido exato de "porque", não o sentido de "que", e introduz a premissa maior que seria encarregada de fornecer a razão da conclusão a ser explicada pelo argumento ("todos os triângulos têm 2R"); (ii) oud', em 168a40, nega precisamente esse hoti e, por isso, nega que a sentença introduzida por ele seja razão adequada para explicar a conclusão. Ainda há uma séria dificuldade concernente à correta intepretação do termo mediador do meu Barbara, mas, considerando as possibilidades em jogo, o resultado formal do passo seria(m) o(s) seguinte(s) silogismo(s):

"Toda figura/ ou toda figura primeira/ ou todo princípio tem $2 \mathrm{R}$ ”

\footnotetext{
${ }^{60}$ Esta é a reconstrução de Schreiber [2003], p. 114. Os tradutores, como Pickard-Cambridge revisado por Barnes, 1984, Dorion e Fait, evitam a quantificação das proposições. Pseudo-Alexandre, 59.31-60.9 parece considerar a duas opções (lendo "ho ti" como equivalente a um quantificador universal). FAIT, 2007, p. 127-8, julga que Aristóteles não estaria interessado na quantificação nesse caso, ao passo que DORION, 1995, p. 249, reconstrói aquilo que poderia ser um Darapti válido (se as premissas fossem quantificadas) e afirma que a conclusão é falsa.

61 Pseudo-Alexandre, 60.23-26, afirma que os homens de ciência são refutados apenas por ignorarem em que consiste uma refutação, mas isso me parece totalmente sem sentido. Alguém não precisa saber qual é a definição de argumento válido para produzir um argumento válido ou para ser capaz de identificar uma falácia flagrante. Alguém não precisa saber qual é a definição de refutação para evitar ser refutado por Dionisodoro a respeito da conclusão "tu és um cachorrinho" (ver final da seção II deste artigo).

62 Essa sintaxe é admitida mesmo pela interpretação tradicional, que julga que Aristóteles esteja negando que a conclusão se segue (cf. SCHREIBER, 2003, p. 114: "it does not follow necessarily"; Fait: "nè é necessario"; Pickard- Cambridge: "it is not proved").
} 


\section{"Todo triângulo é uma figura/ figura primeira/ princípio"}

"Todo triângulo tem 2R".

Nota que a premissa menor desse silogismo é introduzida pelo verbo symbebeke e tem o efeito de sugerir que os termos mediadores assim introduzidos são, neste contexto explanatório, "atributos concomitantes" (cf. 168b7) do termo maior "triângulo".

$\mathrm{O}$ sentido da sentença como um todo seria o seguinte. Ora, mesmo sendo verdade que todo triângulo tem $2 \mathrm{R}$ (conclusão correta do Barbara), mesmo sendo verdade que o todo triângulo tem os atributos em questão (premissa menor verdadeira, para qualquer termo mediador que se escolher), não é pelas razões introduzidas na premissa maior que se explica adequadamente a conclusão em pauta. Como há mais de uma opção para o termo mediador dessa estrutura em Barbara, esse ponto precisa ser subdividido:

(a) se o termo mediador for "figura", a premissa maior se torna falsa (supondo a quantificação típica de um Barbara) e, obviamente, uma premissa falsa não pode explicar uma conclusão verdadeira (cf. Primeiros Analíticos 53b8-10);

(b) se o termo mediador for "figura primeira", no sentido de "figura plana retilínea que é a primeira na ordem das figuras”, então temos não somente uma premissa maior verdadeira, mas um termo mediador que é necessariamente coextensivo com o termo menor. No entanto, a descrição introduzida por tal termo mediador, que capta o triângulo como a primeira figura na ordem das figuras que se pode construir em geometria plana retilínea (na série triângulo, quadrilátero, etc.), ${ }^{63}$ não é relevante para explicar porque todo triângulo tem $2 \mathrm{R}$. Ainda que ela seja necessariamente coextensiva com a descrição que capta o fator explanatório decisivo, ela não o expressa. E é isso que Aristóteles quer dizer: ainda que se tenha um Barbara

\footnotetext{
${ }^{63}$ Isto é, figura de três lados, figura de quatro lados, e assim por diante. Cf. Definição 19 do livro I dos Elementos de Euclides. Aristóteles alusivamente sugere que tal tipo de ordem de "geração das entidades geométricas" estaria em voga ao menos no ambiente dos matemáticos platônicos, ver Metafísica 1077a24-26 ss. Também não é por acaso que a primeira figura a ser construída, na Proposição I do livro I dos Elementos de Euclides, é um triângulo. Creio que, pelas mesmas razões, o triângulo pode ser considerado como "o princípio" das figuras planas retilíneas, e é isso que Aristóteles quer dizer com "arche" em 168b2.
} 
cujo termo mediador seja "primeira figura plana retilínea”, esse atributo será um concomitante no contexto da relação triádica da explicação que se tem em vista, pois não é devido a ele que todo triângulo tem $2 \mathrm{R}$.

Se isto está correto, podemos dizer que Aristóteles parece reconhecer que esses argumentos "por um atributo concomitante" - equivalente ao terceiro tipo de argumento sofístico, aquele que aparenta ser de acordo com a coisa, mas não é - são os argumentos pelos quais impostores tentam refutar até mesmo os especialistas no assunto:

"Mas, neste ponto, tanto os homens de técnica como, em geral, os que têm conhecimento são refutados pelos que não têm conhecimento; pois [estes últimos] produzem argumentos por um atributo concomitante contra os que têm conhecimento, os quais, por sua vez, incapazes de discernir, ou os admitem ao serem perguntados, ou, sem admitir, julgam tê-los admitido" (168b6-10).

É razoável supor que "os que sabem” (epistemones", 168b6, eidotas, 168b8) são os que possuem conhecimento científico: os médicos, os geômetras etc. Sofistas são capazes de os embaraçar na medida em que seus argumentos, ao aparentar trazer explicações mais adequadas para os mesmos fatos, parecem desautorizá-los e mostrá-los como ignorantes na própria arte que professam dominar (medicina, geometria etc.). Essa é "contradição"64 que o sofista lhes dirige. A peirástica consiste em submeter a teste e denunciar falsas pretensões de conhecimento em um dado assunto - seja por meio de princípios comuns meramente formais, que regem a argumentação concludente, seja por meio de conhecimentos comuns. ${ }^{65}$ Já o terceiro tipo de argumento sofístico é aquele que procura parecer desempenhar a tarefa da peirástica e, ao mesmo tempo, "almeja uma demonstração aparente" (171b29): introduzindo uma explicação que apenas aparenta estar de acordo

\footnotetext{
${ }^{64}$ Quero dizer, portanto, que o termo "antiphasis" em 168a36, 37 (bem como em outros contextos das Refutações Sofísticas, como em 169b28) não deve ser tomado no sentido mais técnico envolvido no "quadrado lógico" ou mesmo o sentido formal envolvido em princípios como o Terceiro Excluído. O termo "antiphasis" quer dizer apenas "contradição" no sentido bem mais amplo de "dizer, em uma disputa argumentativa, algo contrário", algo que é de certo modo incompatível com o que o oponente sustentava.

65 Para defesa da segunda opção, ver Bolton, 1990, p. 218-9. Algo similar é proposto em Reeve, 1998, p. 232: os "comuns" seriam os "endoxa", reais ou aparentes.
} 
com a coisa a ser explicada, produz a mera aparência de discernir, nos argumentos dos cientistas, falsas pretensões de conhecimento científico. Pretendendo denunciar impostores, são os próprios sofistas impostores: pretendendo ser bons críticos das pretensões de conhecimento, desautorizam os que têm conhecimento científico.

Como diz Aristóteles:

"As refutações sofísticas, mesmo se chegam a concluir a contraditória, não deixam claro se [o adversário] é ignorante, pois, com tais argumentos, embaraçam até mesmo quem tem conhecimento" (169b27-29).

Não constitui nada surpreendente, neste quadro, a tentativa de definir o conhecimento científico, em 71b9-12, em contraste com o conhecimento ao modo sofístico, produzido por argumentos que selecionam um "atributo concomitante" como pretensa causa a explicar o fato relatado na conclusão. ${ }^{66}$

\section{Referências bibliográficas}

ALEXANDRE DE AFRODISIA. in Aristotelis Sophisticos Elenchos Commentarium (Ed. M. Wallies). Berlin: Reimer, 1898). (aqui referido como Pseudo-Alexandre).

ANGIONI, L. "O conhecimento Científico no Livro I dos Segundos Analíticos de Aristóteles". Revista de Filosofia Antiga (http://www.filosofiaantiga.com/) vol. I, no 2, 2007.

ANGIONI, L. Aristóteles, Física I-II. Campinas: Editora da Unicamp, 2009. ANGIONI, L. "In what sense there is no science of corruptible things: an analysis of Posterior Analytics I 8". Cadernos de História e Filosofia da Ciência vol. 19, n. 1, 2009, pp. 61-87.

\footnotetext{
66 Versões preliminares deste artigo foram discutidas em várias ocasiões. Em 2008, discuti um esboço na UFRGS e agradeço a Raphael Zillig e Alfredo Storck pela oportunidade e pelas sugestões e críticas. Em 2009, discuti as propostas que se encontram nas seções VI-VIII no colóquio "Lost in Logical Space: Aristotle's Sophistici Elenchi", na Humboldt Universitat em Berlim, no qual apresentei 0 paper "Seeming to explain without explaining: Comments on the phainomenos elenchos para to symbebekos (SE 168a34-b10)", e agradeço a muitos pelas sugestões, críticas e discussões: Christof Rapp, Marko Malink, Pieter Sjoerd Hasper, Louis Dorion, Nathanael Stein e Paolo Fait. A este último agradeço especialmente pelo encorajamento no projeto deste artigo.
} 
ANGIONI, L. "Os Seis Requisitos das Premissas da Demonstração Científica em Aristóteles (Segundos Analíticos I 2)”. Manuscrito v. 35, 2012, n. 1, p. 760 .

BARNES, J. "Proof and Syllogism". In: Berti, E. (ed.). Aristotle on Science The Posterior Analytics. Pádua: Editrice Antenore, 1981, p. 17-59.

BARNES, J. (ed.). The Complete Works of Aristotle, 2 vols. Princeton: Princeton University Press, 1984.

BARNES, J. Posterior Analytics. 2.ed. Oxford: Oxford University Press, 1993. BARNES, J. "Philosophy and Dialectic". In: Method and Metaphysics. Essays in Ancient Philosophy I. Oxford: Oxford University Press, 2011/1991), p. 164-173.

BARNES, J. Method and Metaphysics. Essays in Ancient Philosophy I. Oxford: Oxford University Press, 2011.

BEKKER, I. Aristotelis Opera, (editio altera Olof Gigon), Berlin: Walter De Gruyter, 1961.

BERTI, E. (ed.). Aristotle on Science - The Posterior Analytics, Pádua: Editrice Antenore, 1981.

BOLTON, R. "The Epistemological Basis of Aristotelian Dialectic". In: DEVEREUX, D.; PELLEGRIN, P. (eds.), Biologie, Logique et Métaphysique chez Aristote, Paris: Éditions du Centre National de la Recherche Scientifiques, 1990, p. 184-236.

BOSTOCK, D. Space, Time, Matter and Form. Oxford: Oxford University Press, 2006.

DORION, L-A. Les réfutations sofistiques. Paris/Laval: Vrin, 1995.

FAIT, P. Le confutazione sofistiche, Roma-Bari: Laterza, 2007.

FILOPONO. In Aristotelis Analytica Posteriora Commentaria (Commentaria in Aristotelem Graeca vol.XIII) (ed. Maximiliam Wallies). Berlin: Walter de Gruyter, 1909.

GENTZLER, J. (ed.), Method in Ancient Philosophy. Oxford: Clarendon Press, 2011.

HASPER, P. S. "Sources of delusion inAnalytica Posteriora I 5". Phronesis vol. LI, n. 3, 2006, p. 252-284.

HEATH, T. A History of Greek Mathematics. Cambridge: Cambridge University Press, 1921.

HEATH, T. [1949]. Mathematics in Aristotle, Oxford: Clarendon Press. 
HEIBERG, I. L., \& MENGE, H. Euclid: Opera Omnia. Leipzig: Teubner, 1899.

LEAR, J. Aristotle and Logical Theory. Cambridge: Cambridge University Press, 1980.

LLOYD, G. E. R. "The Alleged Fallacy of Hippocrates of Quios”. Apeiron 20, 1987, p. 103-128.

MORRISON, B. "What was Aristotle's concept of logical form?". In: MORRISON, B. \& IERADIAKONOU, K. (eds.). Episteme, etc. Essays in Honour of Jonathan Barnes. Oxford: Oxford University Press, p. 172-188.

MORRISON, B. \& IERODIAKONOU, K. (eds.). Episteme, etc. Essays in Honour of Jonathan Barnes. Oxford: Oxford University Press, 2011.

MUELLER, I. "Aristotle and the Quadrature of the Circle". In: KRETZMANN, N. (ed.), Infinity and Continuity in Ancient and Medieval Thought, Cornell: Cornell University Press, 1982, p. 146-164.

MUÑOZ, A. A. [1998]. "Sobre a definição aristotélica de dialética” Cadernos de História e Filosofia da Ciência, série 3, vol. 8, 1998, n⿳a . especial, p. 127159.

PICKARD-CAMBRIDGE, W. A. Sophistical Refutations (Ed. J. Barnes). The Complete Works of Aristotle. 2 vols. Princeton: Princeton University Press, 1984.

PRITZL, K. O. P. “Opinions as Appearances: Endoxa in Aristotle”. Ancient Philosophyvol. 14, 1994, p. 41-49.

REEVE, C. D. C. "Dialectic and Philosophy in Aristotle". In: GENTZLER, J. (ed.), Method in Ancient Philosophy. Oxford: Clarendon Press, 1998, p. 227252.

ROSS, D. Aristotle's Physics, a revised text with introduction and commentary. Oxford: Clarendon Press,1936.

ROSS, W. D. Aristotle's Prior and Posterior Analytics, Oxford: Oxford University Press, 1949.

SIMPLICIO. in Aristotelis physicorum libros quattuor priores comentaria. H. Diels, Berlin: Reimer, 1895.

SCHREIBER. S. G. Aristotle on False Reasoning. New York: SUNY Press, 2003. 
SMITH, R. Aristotle: Prior Analytics. Indianapolis: Hackett, 1989. . Aristotle: Topics, Books I and VIII. Oxford: Oxford University Press, 1997.

STRIKER, G. Aristotle's Prior Analytics Book I. Oxford: Oxford University Press, 2009.

E-MAIL: angioni.lucas@gmail.com

RECEBIDO: Novembro/2012 APROVADO: Dezembro/2012 